\title{
Exhibition of Arts and Crafts in Vilnius 1924: Tradition or Modernity?
}

\section{Anna Kostrzyńska-Miłosz}

Institute of Art of the Polish Academy of Sciences, Warsaw anna.kostrzynska-milosz@ispan.pl

- The paper analyses the Exhibition of Arts and Crafts opened on 15 September 1924 at the Vilnius Apollo Cinema and presents the press reviews of artistic critics. Particular attention is paid to artistic craftsmanship which demonstrates the attitude of the exhibition's organisers to tradition and modernity. Crafts constituted about two thirds of the exhibits. The section was essentially varied and ranged from the Azarewicz / Azarevich Pottery Workshop decorated, according to the journalist of Przeglad Wilenski in the "native way", to graphic layout proposals of the Lux Publishers. In addition to painting, sculpture, monument designs, and the artistic photography of Bułhak, Siemaszko, Wysocki, and Świętochowska were presented with the comment that they constituted the "prime section of Vilnius artistic activity". Such a wide range of artistic visions allowed various trends in the development of 1920's Vilnius art to be shown.

Keywords: tradition, modernity, folklore, arts and crafts, Vilnius. 
The economic and political situation in Vilnius in the 1920 s was the result of numerous historical events: the beginning of Russification following 1863, German occupation in 1915-1918, and finally a brief three-month Bolshevik occupation until April 1919. All these led to the economic decline of Vilnius ${ }^{1}$. Different attempts were made to change the situation, one of them being the organisation of the Exhibition of Arts and Crafts in $1924^{2}$.

The exhibition was initiated by the well-known Vilnius sculptor, Michał Oszurko, who decided to organise it in order to show the situation of craftsmen exploited by traders ${ }^{3}$. The idea was supported by Ferdynand Ruszczyc and Jerzy Remer. One of the comments read: "Such an exhibition under the patronage of the Government and a group of art experts is meant to reveal the conditions of artistic crafts and industry, in order to help to improve them". However, its organisation proved challenging since: "The Exhibition Organising Committee had only a small number of Vilnius craft workshop addresses" ${ }^{\text {as }}$ as there existed no appropriate office where they would have been registered.

The organising committee included both workshop owners, social activists, and artists affiliated with the Stephen Báthory University Department of Fine Arts. It included: Ferdynand Ruszczyc, Michał Brensztejn, Cezaria Baudouin de Courtenay- Ehrenkreutz, Jerzy Remer, Jeremi Łukaszewicz ${ }^{6}$ Lucjan Uziębło, Anna Mohlówna, Stanisław Linowski, Wacław Czechowicz, Piotr Hermanowicz, Witold Kurman, Jadwiga Poczętowska, and Michał Oszurko, the above-mentioned initiator ${ }^{7}$. Wacław Czechowicz,

1 Dariusz Konstantynów, Wilenskie Towarzystwo Artystów Plastyków 1920-1939 [Vilnius Association of Artists 1920-1939], Warszawa: Instytut Sztuki PAN, 2006, p. 18.

2 Józef Poklewski in his latest study dedicates a mere short paragraph (six lines) to the Exhibition, treating it as of a marginal character; Idem, Studia z historii sztuki i kultury wilenskiej lat 1900-1945 [Studies in History of Art and Culture of Vilnius 1900-1945], Torun: Wydawnictwo Naukowe UMK, 2019.

3 Sulimczyk, "W przygotowaniu do wystawy Sztuki i rzemiosł artystycznych" [In Preparation for the Exhibition of Art and Crafts], in: Stowo, 1924, No. 175, p. 2; Idem, "Otwarcie wystawy Sztuki i Rzemiosł” [Opening of the Exhibition of Art and Crafts], in: Stowo, 1924, No. 209, p. 3.

4 Sulimczyk, "W przygotowaniu do wystawy Sztuki i rzemiosł artystycznych", p. 2.

5 Ibid.

6 Affiliated to the Polish Military Organization (POW) in Vilnius, after: Przemysłąw Dąbrowski, "Struktura i program Polskiego Związku Niepodległościowego Litwy ('Penzel')" [Structure and Platform of the Polish Independence Association of Lithuania ('Penzel')] - contribution to the history of POW in Lithuania and Belarus, in: Przeglad Historyczno-Wojskowy, 2014, No. 15 (66)/2 (248), p. 200.

7 The Organization Committee charged exhibitors $10 \mathrm{zl}$ for the organization purposes, after: "Wystawa sztuki, rzemiosł i przemysłu ludowego" [Exhibition of Art, Crafts, and Folk Industry], in: Dziennik Wileński, 1924, No. 161, p. 3. 
the exhibition's artistic director, was supported by the executive committee made up of the exhibition treasurer and display host Piotr Hermanowicz, himself a sculptor; chairman Witold Kurman, the coach of Industrial Associations at the Vilnius Voivodeship Office; the journalist and socio-cultural activist Lucjan Uziębło ${ }^{8}$; as well as the librarian at Vilnius University Michał Brensztejn ${ }^{9}$. Entry registrations were accepted until 1 September 1924 at the office located at the University Department of Fine Arts (2 Marii Magdaleny Street, now Šventaragio).

The mounting of the display had been planned several months earlier. The competition to design the poster for the exhibition was won by the sculptor Piotr Hermanowicz ${ }^{10}$. Initially, the intention was to display folk art as well as several room interiors, and even the interior of a railway station waiting room. However, it was then decided that the exhibition of folk art would be held as a separate event ${ }^{11}$. The organisers felt that it was most important to display only craft objects, yet this concept was also rejected given the scarcity, excessive simplicity, and the "coarseness" of the proposed exhibits. The overall exhibition formula was defined as "handcraft serving interior decoration"12. It was to be confined to artists and craftsmen from Vilnius alone; the recommendation was for the displayed objects to include ornamental motifs in the local style, so-called "articles de Wilno"13. Lucjan Uziębło, a member of the organising committee, visited 65 Vilnius workshops in order to collect the necessary exhibits. Regrettably, only a small number of craftsmen were interested in participating in the exhibition, possibly for economic reasons. Therefore, it was decided to enrich the display with paintings and textiles, and to also include exhibits from outside Vilnius. These included: woollen and linen textiles by Eugeniusz Mirecki

8 B. Ś., "Wystawa sztuki i rzemiost" [Exhibition of Arts and Crafts], in: Wileński Przegląd Artystyczny, 1924, No. 4, p. 12.

9 L-sław, "Wystawa sztuki i rzemiosł" [Exhibition of Art and Crafts], in: Kurier Wileński, 1924, No. 12, p. 3.

10 "U progu wystawy" [At the Exhibition's Threshold], in: Wilenski Przeglad Artystyczny, 1924, No. 1, p. 14.

11 The exhibition of folk art was planned for April 1925. L-sław, "Wystawa sztuki i rzemiosł" [Exhibition of Art and Crafts], in: Kurier Wileński, 1924, No. 12, p. 3.

12 “Wystawa sztuki, rzemiosł i przemysłu ludowego" [Exhibition of Art, Crafts, and Folk Industry], in: Dziennik Wileński, 1924, No. 161, p. 3; "Wystawa sztuki, rzemiosł i przemysłu ludowego" [Exhibition of Art, Crafts, and Folk Industry], in: Express Wileński, 22 July 1924, p. 4.

13 "Wystawa sztuki, rzemiosł i przemysłu rękodzielniczego" [Exhibition of Art, Crafts, and Handicraft], in: Stowo, 1924, No. 151, p. 3. 


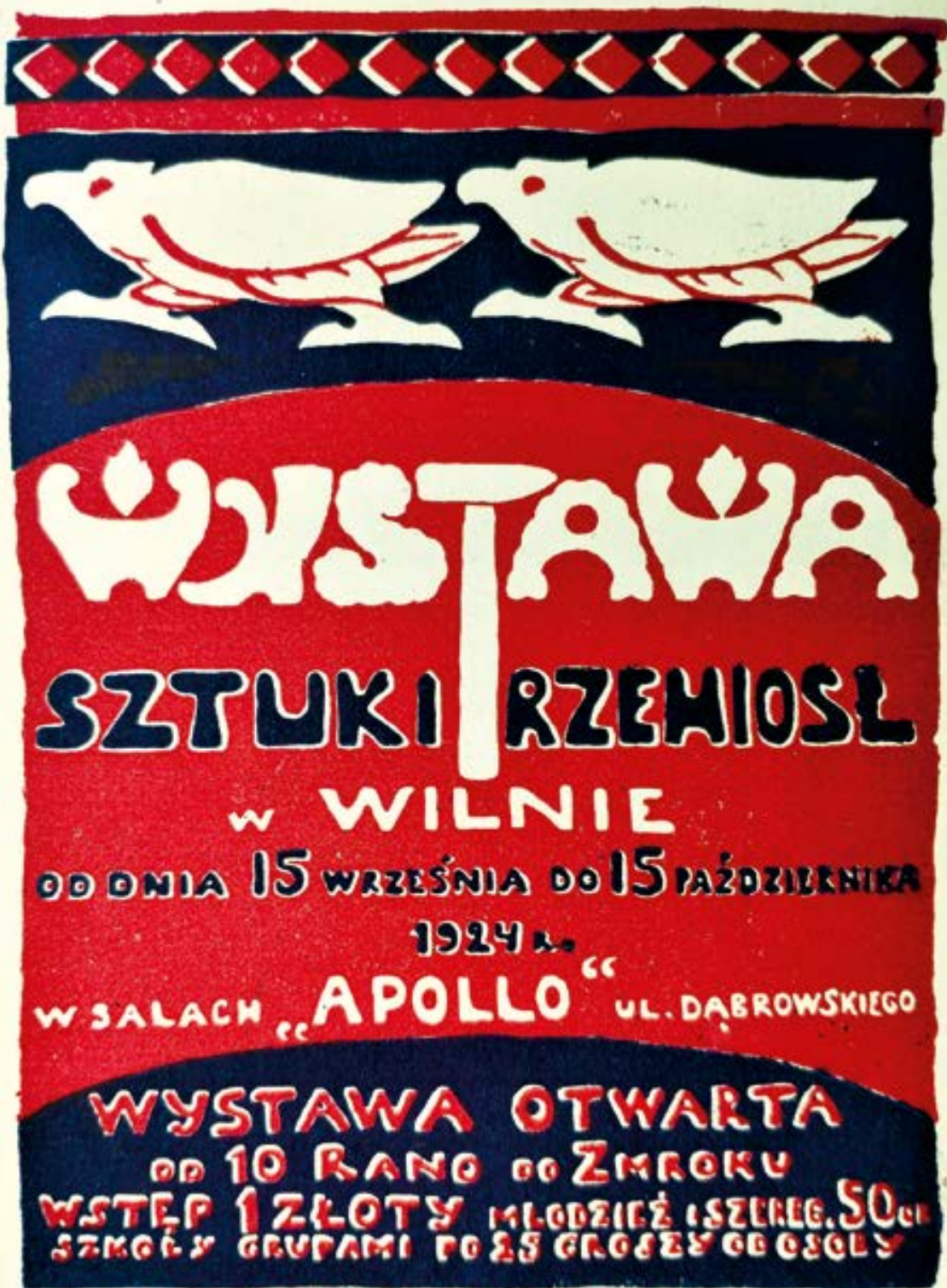

1.

Poster of exhibition, design Piotr Hermanowicz, photo Parodos plakatas, dizainas Piotro Hermanowicziaus A. Kostrzyńska-Miłosz 
of Oszmiana; textile and basket weaving items from Kobrynia, and glass objects from the Niemen Glassworks ${ }^{14}$. (Some sources claim that exhibits from Kalisz and Nowy Sącz were also displayed, however the catalogue does not confirm this information) $)^{15}$.

Original estimations assumed the display of objects from around fifty Vilnius workshops. Eventually, thirty-nine works were gathered. The crafts section in the catalogue lists 117 items, though their names are enigmatic, collective, e.g. oak dining room or locksmith's products.

Launched at the Apollo Cinema on 15 September 1924, the exhibition was much anticipated. Dziennik Wilenski heralded the display with the following words:

\footnotetext{
Thus, already in three weeks the "Apollo" rooms will be crowded with Vilnius residents expecting both aesthetical sensations and an instructive overview of what Polish workshops can offer in the hard times of the post-war period. The Exhibition of Arts and Crafts is to be an attraction here, as well as the first attempt to display a brotherly combination of a palette with a plain, of an artist's burin with a weaver's shuttle. Vilnius would really sin if it did not most eagerly support this aspiration to lead a wealthier existence and to reach forms of a more cultural life. ${ }^{16}$
}

Vilnius Municipality wanted the exhibition to be successful, and so it granted permission to put up exhibition posters throughout the city, as well as at all the railway stations, free of charge. The display was opened "at one p.m. <...> by the Government Delegate Mr Roman”. The exhibition was in the care of the Head of the Section of the Protection of Art Works in the Eastern Borderlands at the Government Representation Mr Jerzy Remer.

The press compared the display to the Arbeitstube Exhibition held in Vilnius under the German occupation, during which Vilnius crafts really impressed the Germans. Painted pots and bowls, "embroidery on canvas, birch-wood items which have now either completely disappeared or become far less popular" were particularly liked. The continuation of these kinds

14 Katalog wystawy sztuki i rzemiost $w$ Wilnie [Catalogue of the Exhibition of Art and Crafts in Vilnius], Wilno, 1924, pp. 12, 14.

15 Polonus, "Przed wystawą" [Before the Exhibition], in: Dziennik Wileński, 1924, No. 192, p. 4 . 


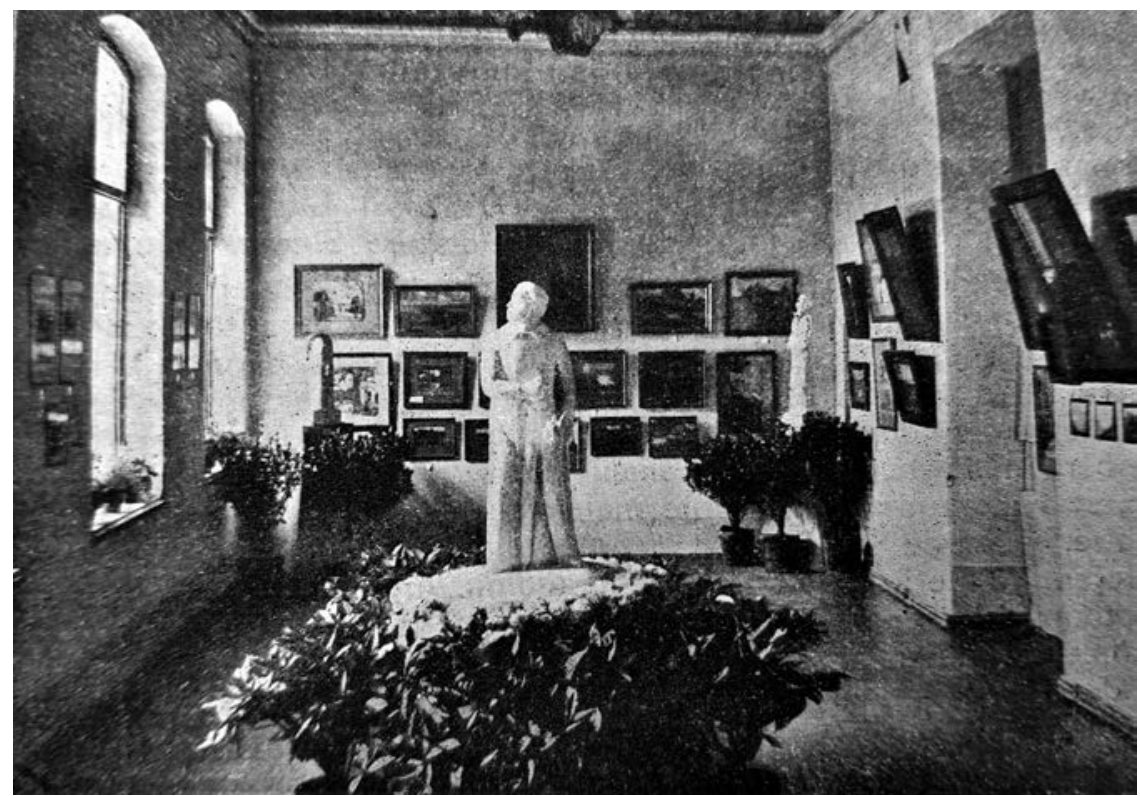

2.

Exhibition of Arts and Crafts in Vilnius 1924, in: Wileński Przeglad Artystyczny, 1924, No. 4, photo

Vilniaus meno ir amatu paroda, 1924

Leonard Siemaszko

of products could be found in the 1924 display in the pottery provided by Maria Downarewiczowa and Aleksander Azarewicz.

The wicker furniture displayed by the Kosz Company and Franciszek Iwanowski was highly appreciated. The remaining furniture, albeit pretty (Sienkiewicz Bedroom, Danielewicz Study), yet not greatly genuine and conservative, was regarded as somewhat heavy.

What stood out were linen and cotton kelims, tablecloths, and towels designed by Maria Zgirskia-Bobrykowa, director of the weaving workshops at the Eukiszki Prison. She herself was a graduate of the Vilnius Anna Mohlówna Weaving School. The role of weaving as a means of rehabilitation was emphasised. Thanks to state subsidies, in 1924, prison workshops had twelve looms as well as forty spinning wheels, and yielded profits. The exhibition displayed seven kelims, linen canvas, and carpentry items made in the Eukiszki prison. 


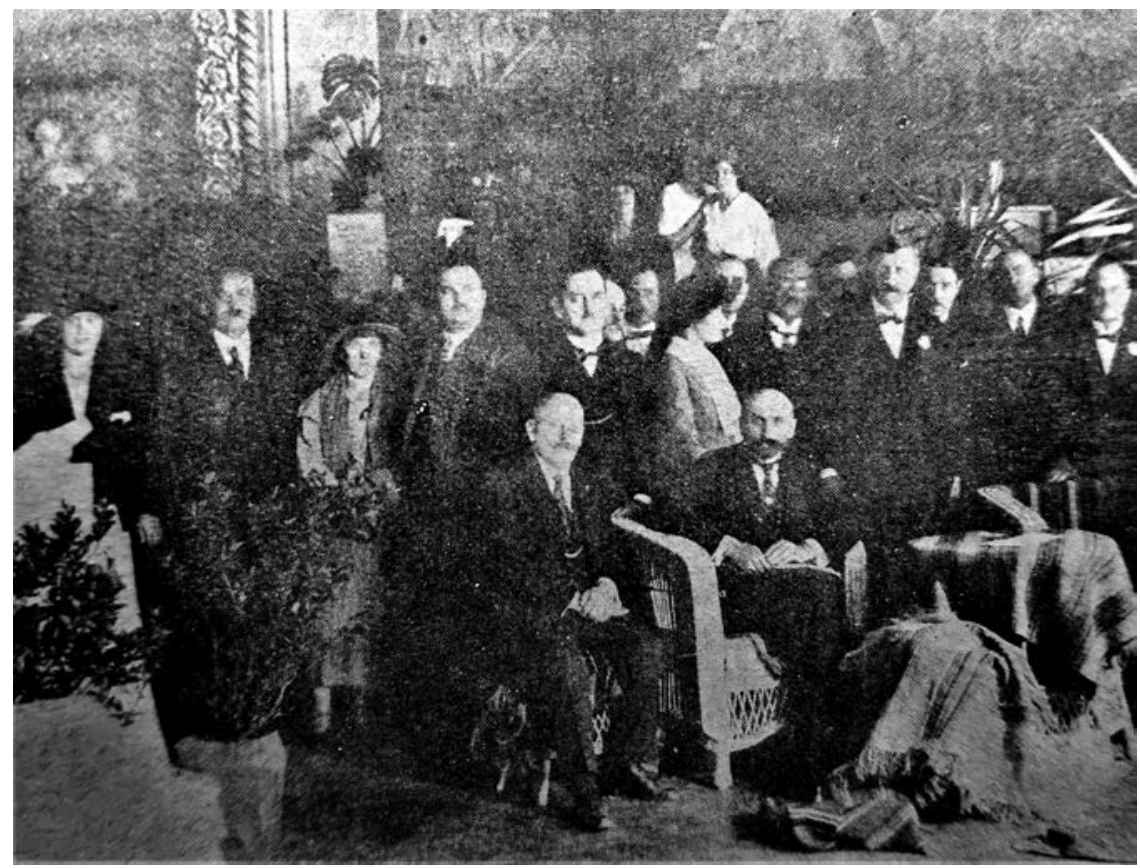

3.

Minister of Industry and Trade Józef Kiedroń at the Exhibition of Arts and Crafts in Vilnius 1924, in: Wileński Przeglad Artystyczny, 1924, No. 4, photo Leonard Siemaszko
Pramonès ir prekybos ministras Józefas Kiedrońas Vilniaus meno ir amatu parodoje, 1924

Apart from craftsmen's workshops, the "academic ladies" of the Stephen Báthory University also presented their applied art. They included the "Green Cat' lady students" workshop displaying embroidery, batiks, crocheted objects, and toys. Women's clothing was displayed by the "Circle of Polish Women" and the "House of Work" of the Polish Social Care Agency for the poor. Hand-made objects were displayed by the St Joseph Vocational School and the State Technical School in Vilnius. The intention to increase the number of handicrafts was thus clearly visible.

It is also worth noting the initiative to collect historical mementoes related to craft guilds dissolved by the "Tsarist authorities", their standards, and royal privileges. This issue was dealt with by the clerk at the Department of Industry at the Vilnius Government Representation, Józef Łepkowski. 
The Circle of Polish Women also organised a café, lectures, and artistic shows ${ }^{17}$; the contribution of women in enthusiastically helping with the organisation of the exhibition was emphasised. These activities may have been initiated by Jadwiga Poczętowska, an activist and education head for the Main Board of the "Polish White Cross". The goal of the Polish White Cross was to promote culture and education, as well as to inspire patriotic attitudes, and national and civic awareness among Polish soldiers doing their military service in the partitioning powers' army, and following the end of World War I, among soldiers doing their military service for the Polish Army ${ }^{18}$.

Furthermore, the photographs displayed at the exhibition, which complemented the furnishing of the rooms, were judged as "unquestionable beauty".

Next to Vilnius landscapes by Mr Bułhak, one can find here women's heads by Mrs Jasieńska, portraits of grand personalities by Mr Siemaszko, Mr Wysocki's cityscapes, and Mrs Świętochowska's portrait studies. First class skills combined with artistic sensitivity place this section of Vilnius creativity at a prominent place. ${ }^{19}$

Painting and sculpture, which were only meant to complete the exhibition, in reality constituted an important component of the display, and were exhibited in two rooms on the first floor ${ }^{20}$.

In relation to Bronisław Jamontt, evaluation ranged from very critical views published in Przeglad Wilensski: "[he] gave a whole array of convulsive and clumsy oddities [...]"21, to flattering ones published by Feliks Lubierzyński in Wileński Przeglad Artystyczny who considered the painter an outstanding individual in creating "painting symphonies"22. The reviewers commended the pastels and watercolours by Władysław Dunin-Marcinkiewicz, as well as the finesse and subtlety of the drawings by Wacław

17 “U progu wystawy”, p. 14.

18 After: "Polski Biały Krzyż" [Polish White Cross], in: Ilustrowana Republika, 1928, No. 323, p. 6.

19 M., "Wystawa sztuki i rzemiosł w Wilnie" [Exhibition of Art and Crafts in Vilnius], in: Przegląd Wilenski, 1924, No. 17, p. 6.

20 Feliks Lubierzyński, “Z wystawy Sztuki i rzemiósł w Wilnie” [From the Exhibition of Art and Crafts in Vilnius], in: Wileński Przeglad Artystyczny, 1924, No. 4, p. 2.

21 M., "Wystawa", p. 6.

22 Feliks Lubierzyński, op. cit., p. 2. 

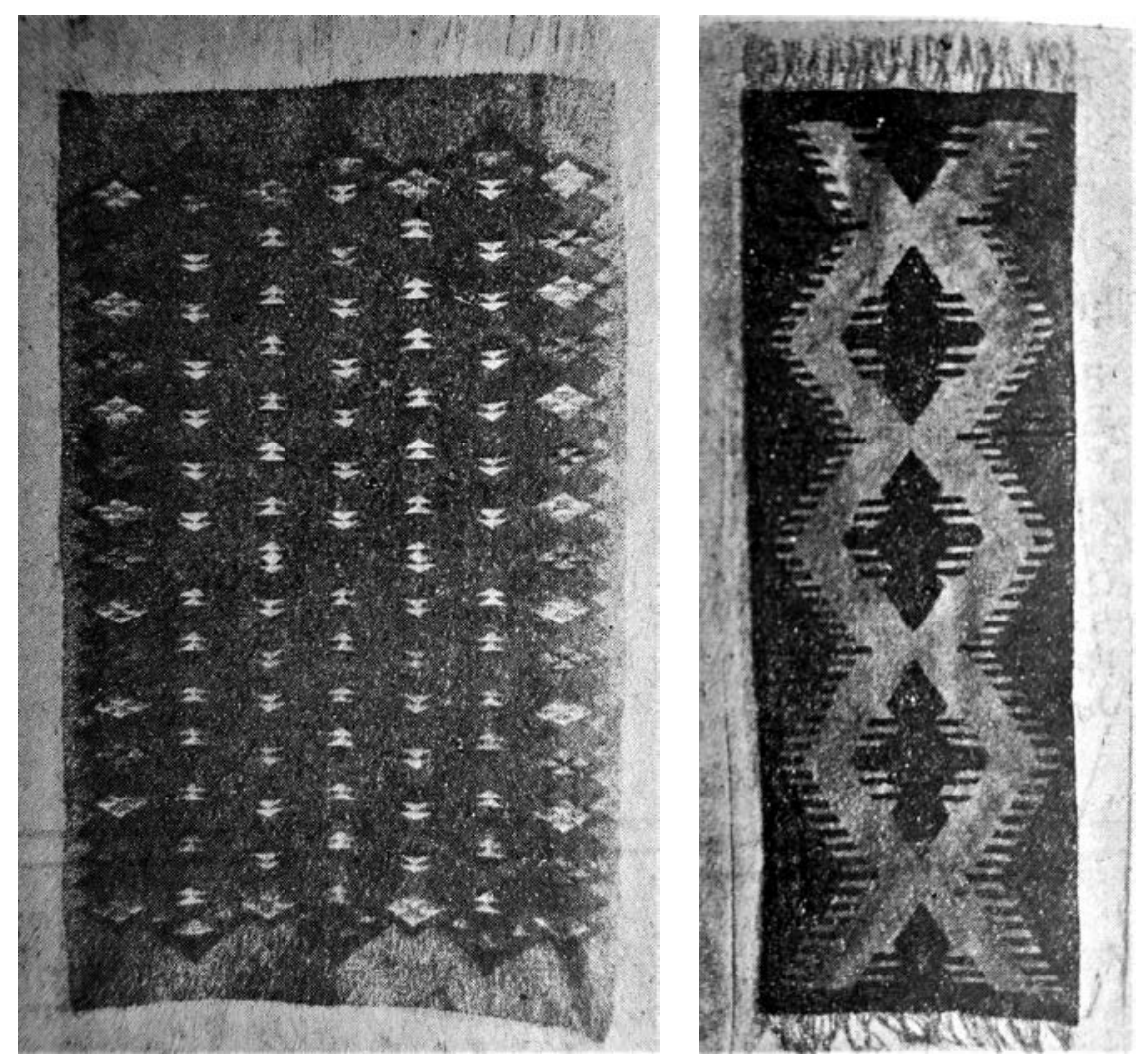

4.

Kilims, exhibited at the "Apollo" cinema 1924. Design Maria Zgirska-Bobrykowa, in: Wileński Przeglad Artystyczny, 1924, No. 6-7, photo Halina Jasińska

Kilimai, eksponuoti „Apollo“ kino teatre 1924 m., dizainas: Maria Zgirska-Bobrykowa

Fleury and Helena Romer. All three: Marian Kulesza, Adam Międzybłocki, Wacław Dawidowski were praised ${ }^{23}$, while there were divergent opinions in the Vilnius press in relation to Czesław Wierusz-Kowalski. Michał Rouba's painting was not well received, as the painter's "stay in Paris has not cured him of peculiar innovatory ideas of treating shapes" ${ }^{24}$. What the reviewers did find interesting was the Śleńdzinski School, with Julian Skangel and Edward Karniej displaying next to it. To sum up, there were two main tendencies observed in painting at the exhibition: academic and a "certain predilection for the form and manner of painting typical of the artists of the

23 Ibid., No. 5, p. 3.

24 'In general, the art section compared to the craft section looks far more interesting and saves the honour of the modest display'. M., "Wystawa", p. 6. 
early Italian Renaissance, namely sentistic and formist, imposed on the majority of the local painters by the powerful artistic individuality of Ludomir Śleńdziński"25.

The only sculpture exhibited was by Piotr Hermanowicz, himself involved in mounting the exhibition, and in the press described as its host ${ }^{26}$.

He displayed as many as five plaster cast designs of Mickiewicz's statute, these conceived symbolically as: a victorious commander, a filaret, a column, and tragedy. The concepts of Mickiewicz's representations with an eagle outstretched on his chest or with a sword and torch in his hands may seem very profound, or, contrariwise, naïve, in either case they cannot leave one indifferent, which in itself can be seen as the artist's certain merit, since it inspires debate, reflection. ${ }^{27}$

The commentators greatly appreciated his bas-reliefs, namely ' $\mathrm{Ni}$ ght', 'Noon', 'Wind', 'Twilight', as well as the sculpture study 'Olympics'28.

"Publications, prints, lithographs constituted as if a complement to a harmonising whole"29. Graphic layouts of books were displayed by Józef Zawadzki's Printing House, Lux, and the Bookshop of the Association of Polish Teachers, while Wilenski Przeglad Artystyczny exhibited monthly issues with the exhibition poster as part of its cover.

The columnist of Przeglad Artystyczny, when summing up the display, wrote: "The painting section had a full representation"30, while furniture and other sections featured much more modest displays. There was criticism of the fact that certain sections of craftsmanship were not displayed at all, e.g. metalwork, leathercraft, hat-making and glove-making ${ }^{31}$. The columnist did not take into account the overall assumption of the organisers that the exhibits were to be firstly objects meant to decorate dwellings.

25 Feliks Lubierzyński, op. cit., p. 2. Since painting of inter-war Vilnius has had an excellent overview provided in his study by Dariusz Konstantynów, for the purpose of this paper I am only giving a short version of the opinions on the matter, focusing on crafts.

26 Piotr Hermanowicz actively contributed to enhancing the quality of crafts in Vilnius. For example, he organised professional drawing courses for craftsmen, the courses being headed by Marian Kulesza. After: Wileński Przeglad Artystyczny, 1924, No. 8-9, pp. 19-20.

27 Feliks Lubierzyński, op. cit., No. 6-7, p. 4.

28 Ibid.

29 B. Ś., op. cit., p. 11.

30 “Otwarcie Wystawy Dzieł Sztuki i Rzemiosł" [Opening of the Exhibition of Art and Crafts], in: Wileński Przeglad Artystyczny, 1924, No. 3, p. 15.

31 M., "Wystawa", p. 5. 


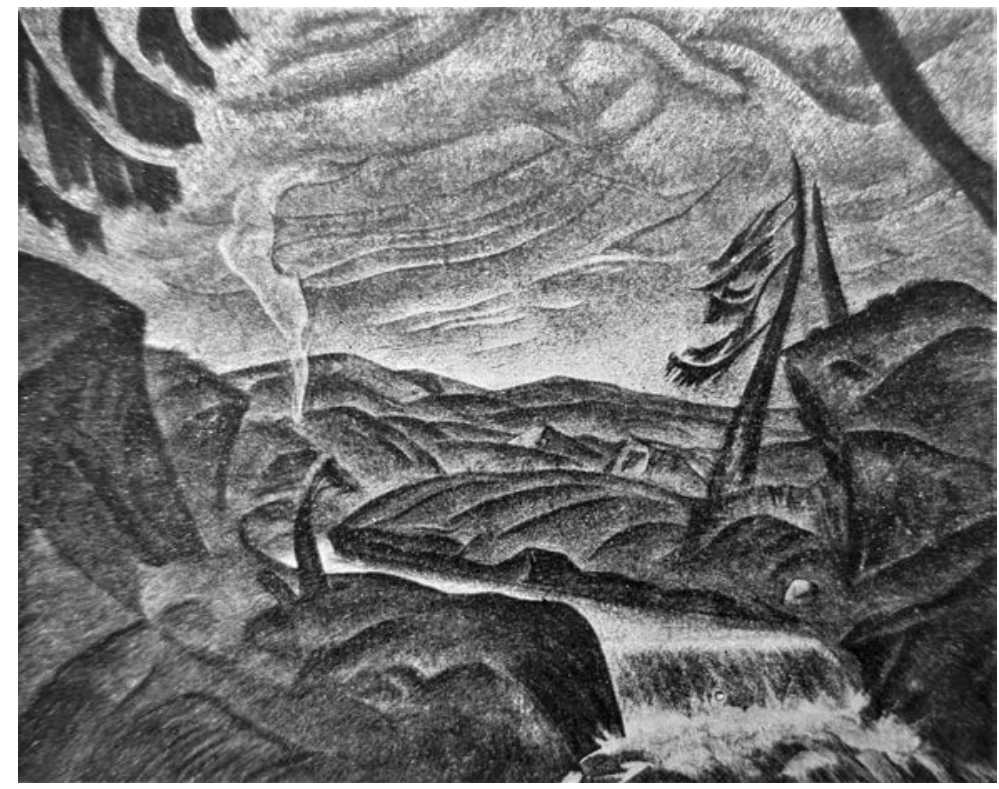

Bronisław Jamontt, Pejzaz z kaskada [Landscape with a cascade], exhibited at the "Apollo" cinema 1924, in: Wileński Przeglad Artystyczny, 1924, No. 5, photo Halina Jasińska
Bronisławas Jamonttas, Peizažas su kaskada, eksponuotas „Apollo“ kino teatre $1924 \mathrm{~m}$.

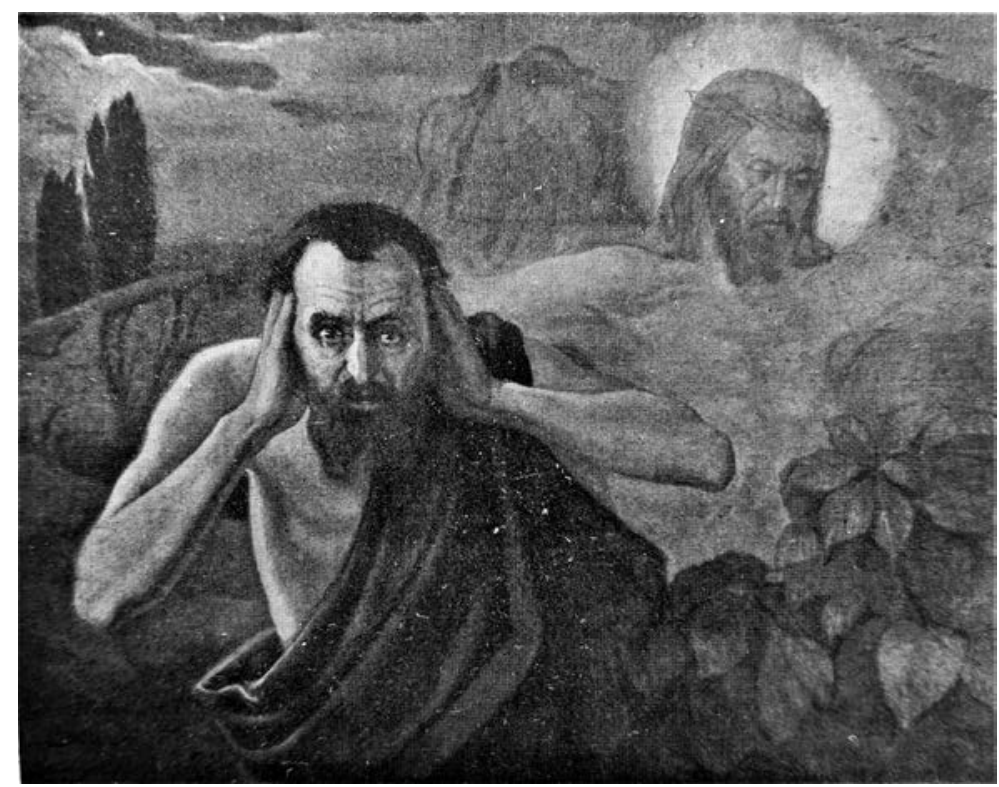

Marian Kulesza, Judasz [Judas], exhibited at the "Apollo" cinema 1924, in: Wileński Przeglad Artystyczny, 1924, No. 5, photo Halina Jasińska
Marianas Kulesza, Judas, eksponuotas „Apollo“ kino teatre $1924 \mathrm{~m}$ 


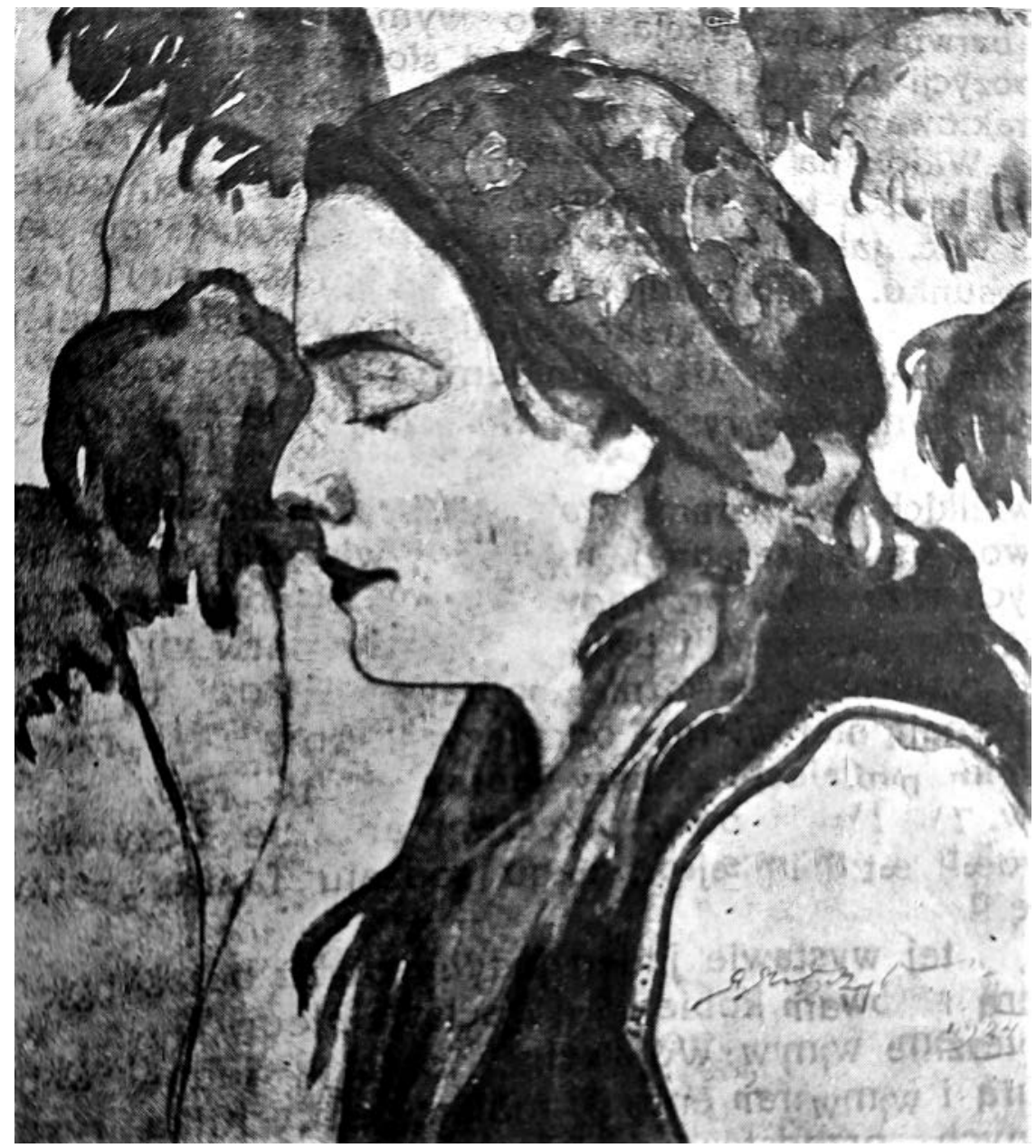

7.

Adam Międzybłodzki, Krakowianka [Cracow girl], exhibited at the "Apollo" cinema 1924, in: Wilenski Przeglad Artystyczny, 1924, No. 5, photo Halina Jasińska
Adamas Międzybłodzkis, Krokuvietè, eksponuota „Apollo“ kino teatre $1924 \mathrm{~m}$. 
The ceremonial closing of the month-long exhibition brought together both the public and all the exhibitors, as well as the committee represented by Ferdynand Ruszczyc, dean of the Department of Fine Arts at Stephen Báthory University, who, in his summing-up remarks, declared the intention to hold this type of display annually ${ }^{32}$. He emphasised that the exhibition had grouped many beautiful exhibits together, that it had been visited by over 7,000 members of the public ${ }^{33}$, including two government ministers. One of them Józef Kiedroń, Minister of Industry and Trade, had given 250 zlotys to Ruszczyc, thus funding exhibition prizes.

The Minister's appreciation should serve as the biggest encouragement for wide sections of society to become acquainted with the art of Vilnius and double the commitment of the exhibition's honourable organisers to continue their important culture-focused work now on a larger scale. ${ }^{34}$

Other prizes, diplomas, and commendations were awarded by Władysław Raczkiewicz, Vilnius Voivode ${ }^{35}$, who extended his gratitude to the organisers for the efforts they had made. The committee highly commended the publishing activity of the Józef Zawadzki Bookshop, which had existed in Vilnius from 1805. Special medals were given to almost all the exhibitors of crafts as well as to the painters: Marian Kulesza, Bronisław Jamontt, Wacław Dawidowski, Czesław Wierusz-Kowalski, Edmund Karniej, Adam Międzybłodzki, and to the sculptor Piotr Hermanowicz. In addition, awards were given to the photographers: Jan Bułhak, Halina Jasińska, Leonard Siemaszko, and to the publishing companies: Bookshop of the Teachers' Association, LUX Printing House, Leonard Pozelis Bookbinding Workshop. Distinctions were given to the Tomasz Korecki Piano Workshop and Michał Oszurka's carpentry shop ${ }^{36}$.

32 "Zamknięcie wystawy sztuk i rzemiosł" [Closing of the Exhibition of Art and Crafts], in: Stowo, 1924, No. 236, p. 3.

33 "Zamknięcie wystawy sztuki i rzemiosł w Wilnie" [Closing of the Exhibition of Art and Crafts in Vilnius], in: Wileński Przeglad Artystyczny, 1924, No. 6-7, p. 5.

34 Ibid.

35 “Zamknięcie wystawy sztuk i rzemiosł" [Closing of the Exhibition of Art and Crafts], in: Stowo, 1924, No. 236, p. 3.

36 F. J.-L., "Z miasta. Zamknięcie wystawy, sztuki rzemiosł w Wilnie” [From the City. Closing of the Exhibition of Art and Crafts in Vilnius], in: Dziennik Wileński, 1924, No. 236, p. 5. 

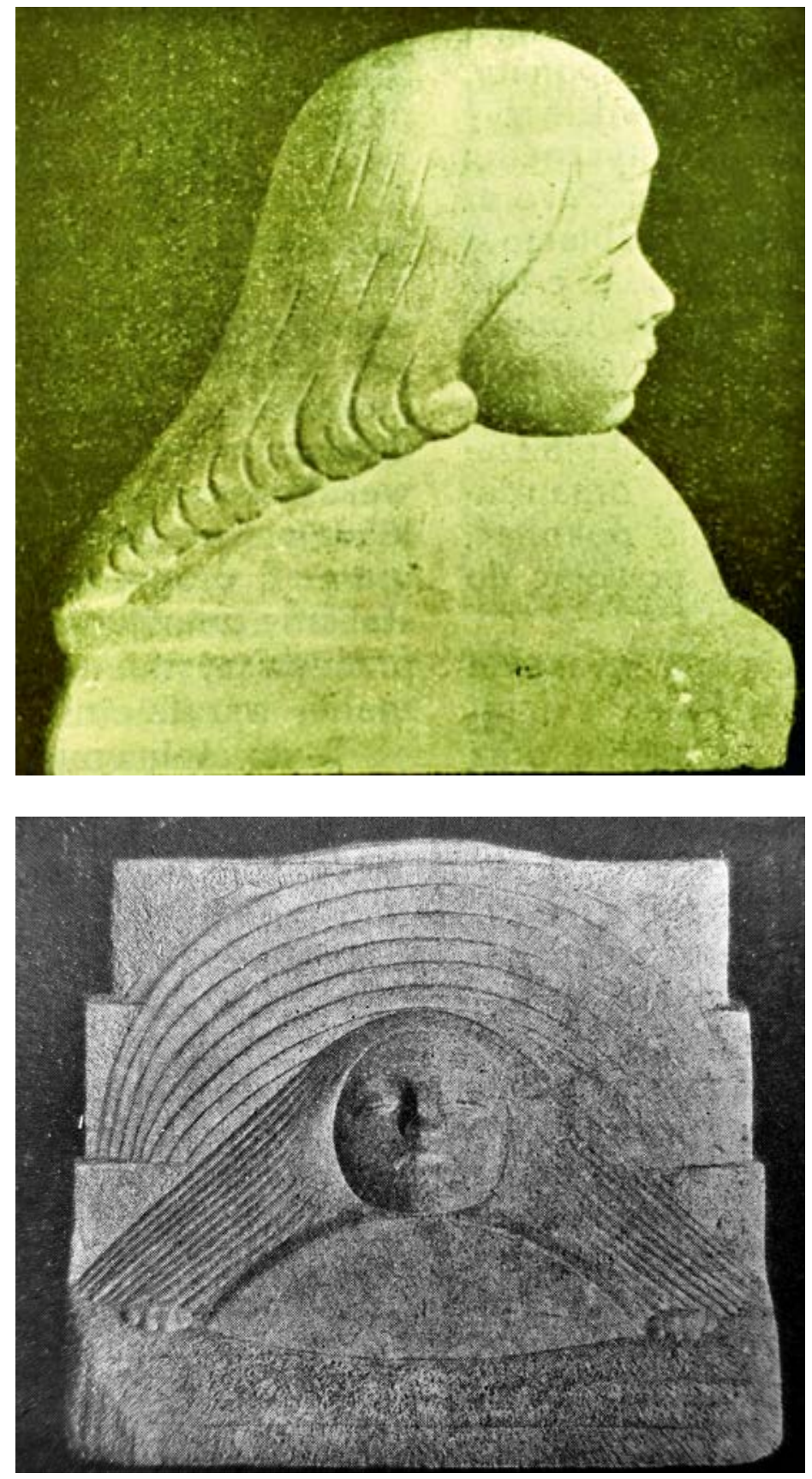

Piotr Hermanowicz, Poranek [Morning]; Noc [Night], exhibited at the "Apollo" cinema 1924, in: Dariusz Konstantynów, Wileńskie Towarzystwo Artystów Plastyków 1920-1939 [Vilnius Association of Artists 1920-1939], Warszawa, 2006, reprod. Anna Kostrzyńska-Miłosz
Piotras Hermanowiczius, Rytas, Naktis, darbai eksponuoti „Apollo“ kino teatre $1924 \mathrm{~m}$. 
Complaints were voiced that so few art works were purchased, this fact was blamed on the economic crisis $^{37}$. The exhibition declared a profit of 1,277 zlotys $^{38}$.

Did the exhibition have an impact? Handcrafts clearly tended towards the tradition, the folklore, and were conservative. Nevertheless, the exhibition drew attention to crafts as a domain of art constituting an integral part of man's surroundings, and the need to introduce new forms of objects. It was innovative to display crafts alongside painting and sculpture, the latter featuring more modern forms.

The exhibition's unquestionable goal was to “illustrate cultural achievements $<\ldots>$ from the revival of the Polish State up to the current time, and the encouragement of creative activity and its enhancement" It should be remembered that it was only as of February 1922 that Vilnius belonged to Poland. Therefore, the exhibition was also of a propaganda nature in its political dimension. It was defined as: "The first after the revival of Poland collective display of native output of crafts and industry of the middle class" ${ }^{40}$. The comments on the exhibition were encouraging, and it unquestionably integrated many of the different circles of Vilnius: artists, craftsmen, and social activists. In the eyes of the Wilenski Przeglad Artystyczny journalist: “The Exhibition, most entertaining in every aspect, proved the vitality of Vilnius artists, working in their modest studios for the sake of culture and art" ${ }^{41}$.

\section{Submitted - 08/02/2020}

37 Feliks Lubierzyński, op. cit., No. 6-7, p. 4.

38 In: Stowo, 1924, No. 276, p. 3.

39 "Wystawa sztuki, rzemiosł i przemysłu ludowego" [Exhibition of Art, Crafts, and Folk Industry], in: Kurier Wileński, 1924, No. 19, p. 3.

40 F. J., "Na wystawie sztuk i rzemios»" [At the Exhibition of Art and Crafts], in: Kurier Wileński, 1924, No. 71, p. 2.

41 B. Ś., op. cit., p. 11. 


\section{Bibliography}

B. Ś., "Wystawa sztuki i rzemiosł" [Exhibition of Arts and Crafts], in: Wileński Przeglad Artystyczny, 1924, No. 4.

Dąbrowski Przemysław, "Struktura i program Polskiego Związku Niepodległościowego Litwy ('Penzel')" [Structure and Platform of the Polish Independence Association of Lithuania ('Penzel')] - contribution to the history of POW in Lithuania and Belarus, in: Przeglad Historyczno-Wojskowy, 2014, No. 15 (66)/2 (248).

F. J., "Na wystawie sztuk i rzemiosł" [At the Exhibition of Art and Crafts], in: Kurier Wileński, 1924, No. 71.

F. J.-L., "Z miasta. Zamknięcie wystawy, sztuki rzemiosł w Wilnie" [From the City. Closing of the Exhibition of Art and Crafts in Vilnius], in: Dziennik Wileński, 1924, No. 236.

Katalog wystawy sztuki i rzemiost $w$ Wilnie [Catalogue of the Exhibition of Art and Crafts in Vilnius], Wilno, 1924.

Konstantynów Dariusz, Wileńskie Towarzystwo Artystów Plastyków 1920-1939 [Vilnius Association of Artists 1920-1939], Warszawa: Instytut Sztuki PAN, 2006.

Lubierzyński Feliks, "Z wystawy Sztuki i rzemiósł w Wilnie" [From the Exhibition of Art and Crafts in Vilnius], in: Wilenski Przeglad Artystyczny, 1924, No. 4, 5, 6-7.

L-sław, "Wystawa sztuki i rzemiosł" [Exhibition of Art and Crafts], in: Kurier Wileński, 1924, No. 12.

M., "Wystawa sztuki i rzemiosł w Wilnie"

[Exhibition of Art and Crafts in Vilnius], in: Przegląd Wileński, 1924, No. 17.

"Otwarcie Wystawy Dzieł Sztuki i Rzemiosł" [Opening of the Exhibition of Art and Crafts], in: Wilenski Przeglad Artystyczny, 1924, No. 3.

Poklewski Józef, Studia z historii sztuki i kultury wileńskiej lat 1900-1945 [Studies in History of Art and Culture of Vilnius 1900-1945], Toruń: Wydawnictwo Naukowe UMK, 2019.
Polonus, "Przed wystawą" [Before the Exhibition], in: Dziennik Wileński, 1924, No. 192.

"Polski Biały Krzyż" [Polish White Cross], in: Ilustrowana Republika, 1928, No. 323.

Sulimczyk, "Otwarcie wystawy Sztuki i Rzemiosł" [Opening of the Exhibition of Art and Crafts], in: Stowo, 1924, No. 209.

Sulimczyk, "W przygotowaniu do wystawy Sztuki i rzemiosł artystycznych" [In Preparation for the Exhibition of Art and Crafts], in: Stowo, 1924, No. 175.

"U progu wystawy" [At the Exhibition's Threshold], in: Wilenski Przeglad Artystyczny, 1924, No. 1.

"Wystawa sztuki, rzemiosł i przemysłu ludowego" [Exhibition of Art, Crafts, and Folk Industry], in: Dziennik Wileński, 1924, No. 161.

"Wystawa sztuki, rzemiosł i przemysłu ludowego" [Exhibition of Art, Crafts, and Folk Industry], in: Express Wilenski, 22 July 1924.

"Wystawa sztuki, rzemiosł i przemysłu ludowego" [Exhibition of Art, Crafts, and Folk Industry], in: Kurier Wileński, 1924, No. 19.

"Wystawa sztuki, rzemiosł i przemysłu rękodzielniczego" [Exhibition of Art, Crafts, and Handicraft], in: Stowo, 1924, No. 151.

“Zamknięcie wystawy sztuk i rzemiosł” [Closing of the Exhibition of Art and Crafts], in: Stowo, 1924, No. 236.

"Zamknięcie wystawy sztuki i rzemiosł w Wilnie" [Closing of the Exhibition of Art and Crafts in Vilnius], in: Wilenski Przeglad Artystyczny, 1924, No. 6-7. 


\title{
Santrauka
}

\section{4 m. Vilniaus meno ir amatu paroda: tradicija ar modernumas?}

\begin{abstract}
Anna Kostrzyńska-Miłosz
Reikšminiai žodžiai: tradicija, modernybè, folkloras, menas ir amatai, Vilnius.

Straipsnyje aptariama 1924 m. rugsėjo 15 d. Vilniaus „Apollo“ kino teatre atidaryta Vilniaus meno ir amatu paroda ir pateikiamos spaudos bei meno kritikų apžvalgos. Parodoje ypatingas dėmesys buvo skirtas amatams, kas tuo pačiu demonstravo organizatorių požiūrị ị tradicijas ir modernybę. Amatininkų dirbiniai sudarè maždaug du trečdalius visos parodos. Amatų sekcija buvo itin įvairi - nuo puodininkystės, pavyzdžiui, Azarewicziaus dirbtuvėje pagamintų ir, pasak Przegląd Wileński žurnalisto, „vietine maniera“ padabintų puodų, iki „Lux“ leidyklos pristatytų grafikos maketų. Greta tapybos, skulptūros ir monumentaliosios dailès buvo pristatyta ir Bułhako, Siemaszko, Wysockio bei Świętochowskos meninė fotografija, kuri, pasak komentatorių, sudarè „pagrindinę Vilniaus menininkų veiklos dalị“. Toks platus meninių vizijų diapazonas leido pasireikšti ịvairiausioms 3 deš. Vilniaus meno kryptims.
\end{abstract}

